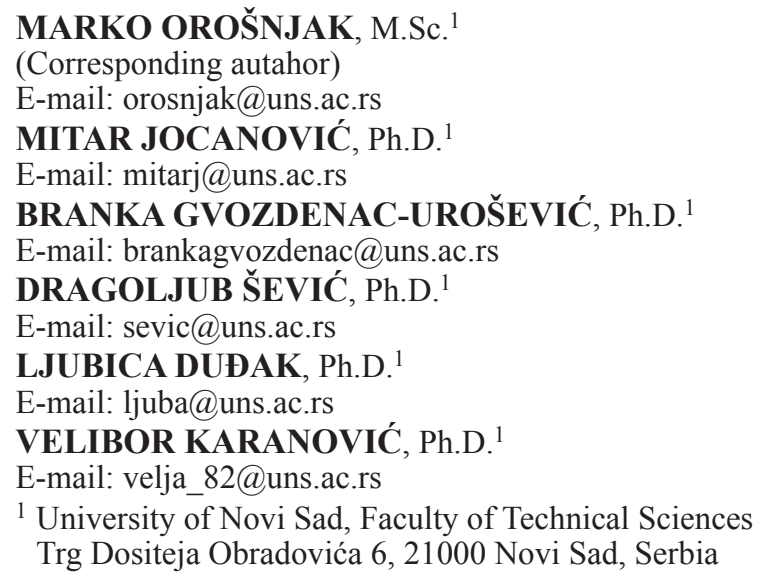

Transport Engineering Review

Submitted: 10 Dec. 2019 Accepted: 30 July 2020

\title{
BUS FLEET MANAGEMENT - A SYSTEMATIC LITERATURE REVIEW
}

\begin{abstract}
The research on Bus Fleet Management (BFM) has undergone significant changes. It is unclear whether these changes are accepted as technological change or as a paradigm shift. Perhaps unintentionally, BFM is still perceived as routing and scheduling by some, and by others as maintenance and replacement strategy. Therefore, the authors conducted a Systematic Literature Review (SLR) to overview the existing concepts and school of thoughts about how stakeholders perceive the BFM. The SLR post-study exposed that BFM should be acknowledged as a multi-realm system rather than a uniform dimension of fulfilling timely service. Nonetheless, the work encapsulates BFM evolution which shows the need for the multi-realm research abstracted as "Bus Fleet Mobility Management" and "Bus Fleet Asset Management". The difficulties of transport agencies and their ability to switch from conventional to Zero-Emission Buses (ZEBs) illustrates why we propose such an agenda, by which the research is validated through needs both in academia and in practice.
\end{abstract}

\section{KEY WORDS}

bus fleet management; bus fleet mobility management; bus fleet asset management; systematic literature review;

\section{INTRODUCTION}

The transport industry is an integral part of the economy, and in the EU employs directly around 10 million people accounting for about 5\% of GDP [1]. According to UITP [2], 243 billion transport journeys are made per year in 39 countries, while $63 \%$ is by public transport. Even though these numbers stress out the social and economic impact, transit agencies need to evolve beyond the environmental impact $[3,4]$ and move towards the concept of integrated sustainability [5]. Hence, the fleet managers should no longer be solely responsible for routing and scheduling problems; on the contrary, they must rely on performance associated with fuel economy [6], availability [7-9], operational efficiency [10, 11], life cycle management [12], and pollution [13, 14] - highlighting the complexity of decision-making in the BFM domain. The term Bus Fleet Management started appearing during the 1970s where Hauslen [15], and later Roth [16], discussed the benefits of AVM (Automated Vehicle Monitoring) to resolve the issues of "bunching" (simultaneous arrival of buses). Afterwards, Maze et al. [17] in a report "The Bus Fleet Management Techniques Guide" gave fully documented data of bus failures. The report contained systematically analysed failures of brake shoes, transmissions, and air compressors, providing easy-to-access data for maintaining the fleet. Hence, in early stages, BFM research was mostly concerned with the maintenance, eventually shifting the focus on routing and scheduling [18], with the tasks of detecting accidents [19], tracking location [20], and advising drivers [21]. Today's practice consists of mobility optimisation and asset-intensive issues in respect to energy management [22-25]; asset management [12, 26, 27], purchasing [28], replacements [29-31]; ensuring service life [32]; and maximising profit [33]. To 
unplait the complexity of BFM tasks, the authors will give a brief overview of the BFM and BFMS (Bus Fleet Management System), and the differences within.

\subsection{Bus Fleet Management and Bus Fleet Management System}

There are many propositional aspects and concepts of the BFM. For example, Hounsell [34] defines BFM as Fleet Management and Operations (FMO) application of the city bus location information available for fleet managers to take actions in case of disruptions [35, 36]. Adding architectures of RTI (real-time information) and AVL (Automatic Vehicle Location) system, BFM extends into a Dynamic Bus Fleet Management (DBFM) [37]. Moreover, Polyviou [36] further expands DBFM to develop SIBUFEM (Simulation Incidents Bus Fleet Management) as a model used to address traffic-related incidents. Additionally, Southworth et al. [38] state that BFM belongs to a wide range of operation and maintenance $(\mathrm{O} \& \mathrm{M})$ activities $[38,39]$ aimed at reducing fuel consumption. In contrast, some [40] classify BFM into fleet maintenance and fleet replacement problems [41], where BFM uses a variety of strategies for early replacement [39, 42-44] concerning pollution reduction and energy optimisation [45-48]. Even though all concepts aim to improve bus availability, there is a difference between mobility and asset issues. In that sense, the authors propose, while some [49] agree, that "mobility management", instead of "fleet management", is the right term to be used when addressing the issues of routing and scheduling within the management system.

Bus Fleet Management System (BFMS), on the other hand, is perceived as a decision-making system aimed at supervising, controlling, and managing the fleet of buses. The activities within the decision-making system consist of, but are not limited to, O\&M costs optimisation, pollution reduction, routing, and scheduling activities. There are different definitions of BFMS present in the literature. For instance, the Institute of Transport Studies [50] defines BFMS as "A system which facilitates the efficient management and scheduling of bus routes to ensure that buses run as per schedule". Zhou [51] states that BFMS operates using AVL devices that exchange information between bus and Bus Fleet Management Centre (BFMC). Taking into account the management centre, Bivona \& Montemaggiore
[7] state that the BFMS consists of four sectors: asset sector, maintenance sector, maintenance and human resource sector, and production sector, where every sector by itself consists of distinctive activities. Unlike these traditional systems aimed at reducing costs and providing timely service, the West Virginia University [52] developed an Integrated Bus System (IBIS) with additional data, including emission and fuel consumption. The IBIS system uses these data as a valuable source for fleet optimisation. Thus, understanding that BFMS is getting more sophisticated, Vaughan et al. [12, 27, 53] developed an interactive expert computer-based tool dedicated to fleet managers in aiding decision-making, taking into account four goals, namely: technological, economic [54], transportation [55], and environmental [56]. Besides, the development of ITS (Intelligent Transport System) architecture, digitalisation, and IoT (Internet-of-Things) facilitate the decision-making process considering these interrelated issues [46]. However, looking over the concepts it seems as if BFM is intertwined between mobility issues and asset issues, which is one of the drivers for the research. In addition, the aim of the paper does not include explaining all the myriad ITS support system architectures using real-time support system for analytical purposes, but to critically appraise the current state-of-the-art issues by decomposing the complexity of BFM and improving the management decision-making.

\subsection{Research questions and hypothesis}

The need for this study is provoked by inadequate elucidation of BFM, which led the authors to use a systematic approach to decompose the BFM based on mobility and management targets. Therefore, this study will answer the following questions: RQ1: What does state-of-the-art bus fleet management represent, and what are the evolutions of the bus fleet management over time?

Following the first question, the authors point out that BFM is misinterpreted, and the hypothesis is that BFMM is an appropriate epitome when addressing routing and scheduling issues. Hence, the second question states:

RQ2: What is the difference between bus fleet management and bus fleet mobility management?

The rest of the paper is summarised as follows. Section 2 explains the methodology used to perform SLR research. Section 3 transparently shows the retrieval of studies and data insights. Section 4 
consists of the discussion and hypothesis validation based on the aims of the research regarding the research questions proposal. The final section consists of concluding remarks and future research recommendation.

\section{RESEARCH METHODOLOGY}

The research methodology builds upon EBP (Evidence-Based Practice) and ORS (Objective Review Strategy), which is motivated by various guidelines [57-60]. The purpose of the EBP is that it assures transparency and replicability while ratifying the methodology in more rigorous and challenging manner. The objective of ORS is that all of the authors must reach a consensus on whether to include the article in the corpus. Unlike traditional narrative and critical review, the precedence of SLR is that aids peers towards evidence-based approach, assuring replication of results and data synthesis clearness.

\subsection{Databases with Inclusion and Exclusion (I/E) criteria}

Based on the research questions, the authors used the following keywords with Boolean operators for databases:

Table 1 - Description of I/E criteria for semantic search
1) ("transit bus*" AND "fleet management") OR "bus fleet management";

2) ("city bus*" OR "transit bus*") AND "public bus transport";

3) "urban transport" AND "city bus*" AND ("transit fleet management" OR "fleet management");

4) "transit fleet management" AND "public transport" AND "bus*".

The proposed semantic search was used to search within SCOPUS and EBSCOhost. The SCOPUS is the largest database of peer-review articles, while EBSCOhost consists of Springer, John Wiley \& Sons, PLOSone, Elsevier (ScienceDirect) and others. Besides, the authors included Google Scholar, for additional papers, respecting ORS and I/E criteria (Table 1).

\subsection{Flow diagram for conducting the search}

This SLR process was conducted in two phases (Figure 1). Phase one includes the first three steps defined in an SLR process, i.e. through screening of titles and abstracts up to the point of Exclusion (LR) criteria. By formulating the research question, search strings are modified to narrow the search in databases. After finishing the process of evaluation based on NR exclusion criteria, 93 papers remained

\begin{tabular}{|c|c|c|}
\hline $\mathrm{I} / \mathrm{E}$ criteria & Criteria & Description of criteria \\
\hline \multirow{4}{*}{ Inclusion criteria } & Full-text (FTP) & Full-text papers - no posters, presentation or abstracts. \\
\hline & Language (LAN) & Full text of the article must be written in English. \\
\hline & Time frame $(\mathrm{TF})$ & Published between 01.01.2009 - 31.12.2018. \\
\hline & Studies selected (SS) & $\begin{array}{l}\text { Journal articles, conferences, technical papers, book chapters, working papers, } \\
\text { reports, and doctoral thesis. }\end{array}$ \\
\hline \multirow{8}{*}{$\begin{array}{l}\text { Exclusion } \\
\text { criteria }\end{array}$} & \multirow{4}{*}{ Non-related (NR) } & $\begin{array}{l}\text { NR1: Papers that still appear as search results but are not articles (e.g. editorial } \\
\text { material, procedures, etc.) }\end{array}$ \\
\hline & & $\begin{array}{l}\text { NR2: Papers that are not dealing with "city buses" but reference them (e.g. abstract, } \\
\text { keywords, references). }\end{array}$ \\
\hline & & $\begin{array}{l}\text { NR3: Reports of transit agency characteristics (e.g. procedures, and bus fleet } \\
\text { statistics). }\end{array}$ \\
\hline & & NR4: Papers that are dealing with multimodal traffic. \\
\hline & \multirow{4}{*}{ Loosely-related (LR) } & $\begin{array}{l}\text { LR1: Article is addressing bus fleet management influence on infrastructure } \\
\text { problems. }\end{array}$ \\
\hline & & $\begin{array}{l}\text { LR2: Article is not related to transit (city) buses (e.g. inter-city buses (coaches), } \\
\text { vans, minibuses, etc. }\end{array}$ \\
\hline & & $\begin{array}{l}\text { LR3: Article relates to transport management (e.g. metro, taxies, and other } \\
\text { rail-based systems). }\end{array}$ \\
\hline & & LR4: Article is dealing with bus powertrain issues. \\
\hline
\end{tabular}



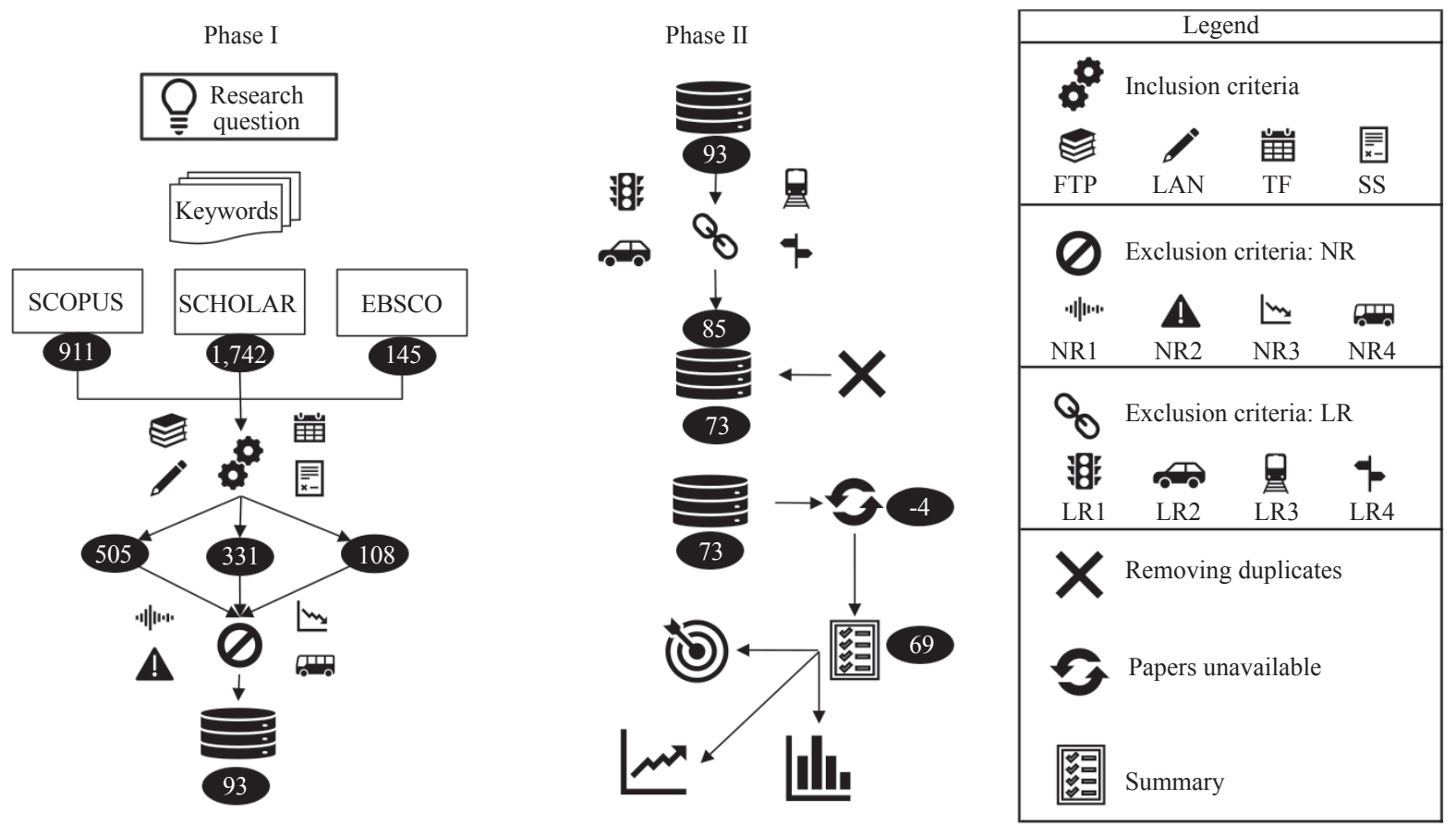

Figure 1 - Algorithm for conducting a systematic literature review

for in-depth analysis. Phase II followed an exhaustive review of studies concerning LR criteria. After the review process, the authors ended up with 73 papers, of which four papers were unavailable to the authors.

\section{RESULTS}

\subsection{Summary of studies}

The results show that most of the publications (Figure 2) are journal articles (44) and conference proceeding papers (14), followed by dissertations (4), chaptered books (3), reports (2), technical paper (1), and working paper (1). The results additionally show that studies rely on simulation and modelling with practical case studies (Figure 3) by which most studies include a comparison of DBs in with other technologies showing the need for evaluating the benefits and opportunities of new technologies. The authors would like to emphasise that no study showed research on a full battery or fuel cell fleet of buses.

\subsection{Aims of the studies}

The research on BFM topic usually included mobility management issues until, and during the 2000s with a little emphasis on minimisation on

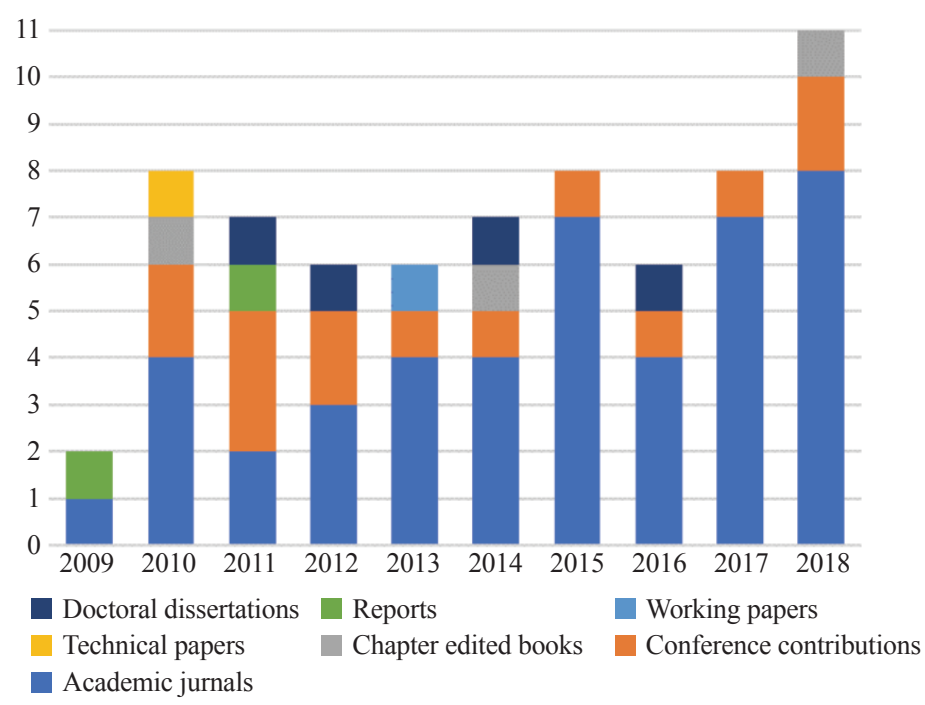

Figure 2 - Type of publications by year 


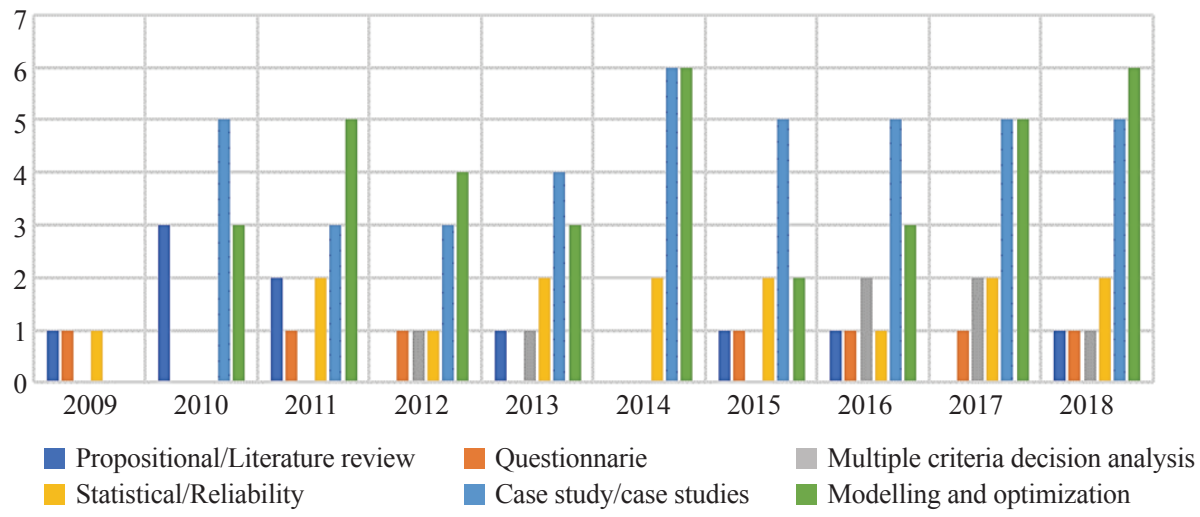

Figure 3 - Types of research method across studies

energy and pollution. However, with the advent of EURO norms, the issues started becoming complicated, shifting more attention to reducing environmental pollution and focusing on replacement and retrofitting strategies (Figure 4). Still, the research on mobility issues stayed active due to the expansion of sensor technology (e.g. RFID [61] and ZigBee [62]), internet architectures, and communication technologies (multi-agent systems, AI, IoT, etc.). In this period, BEBs and FCEBs were still considered as technology infants, i.e. in early Technology Readiness Level (Figure 5), and only the concepts hit the market. However, the research after 2013 shifts the focus from pollution and mobility issues (Figure 4) towards the bus replacement strategies and sustainable energy issues, due to battery

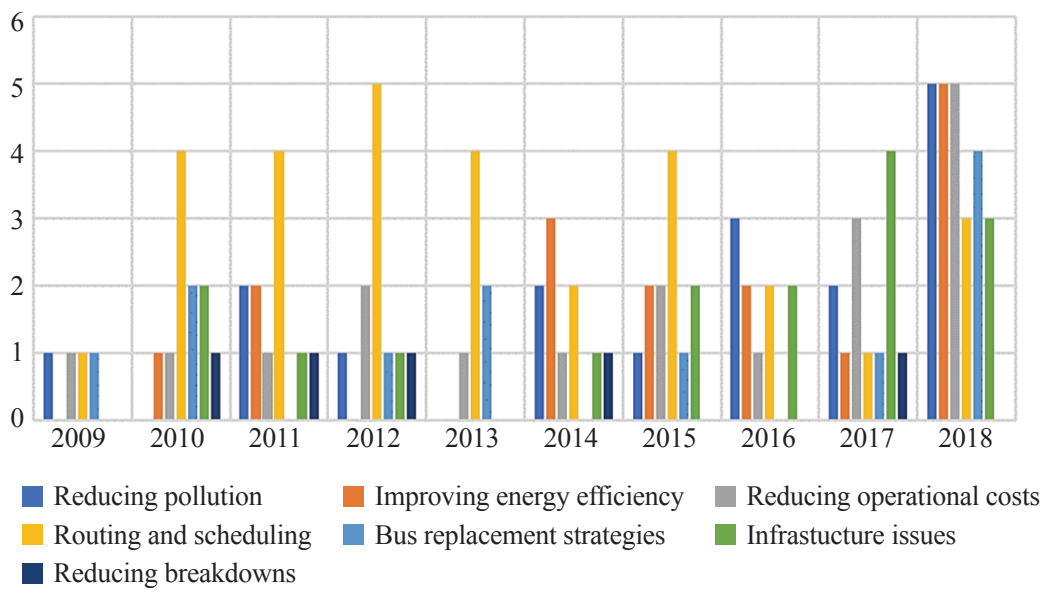

Figure 4 - The research aims within the studies

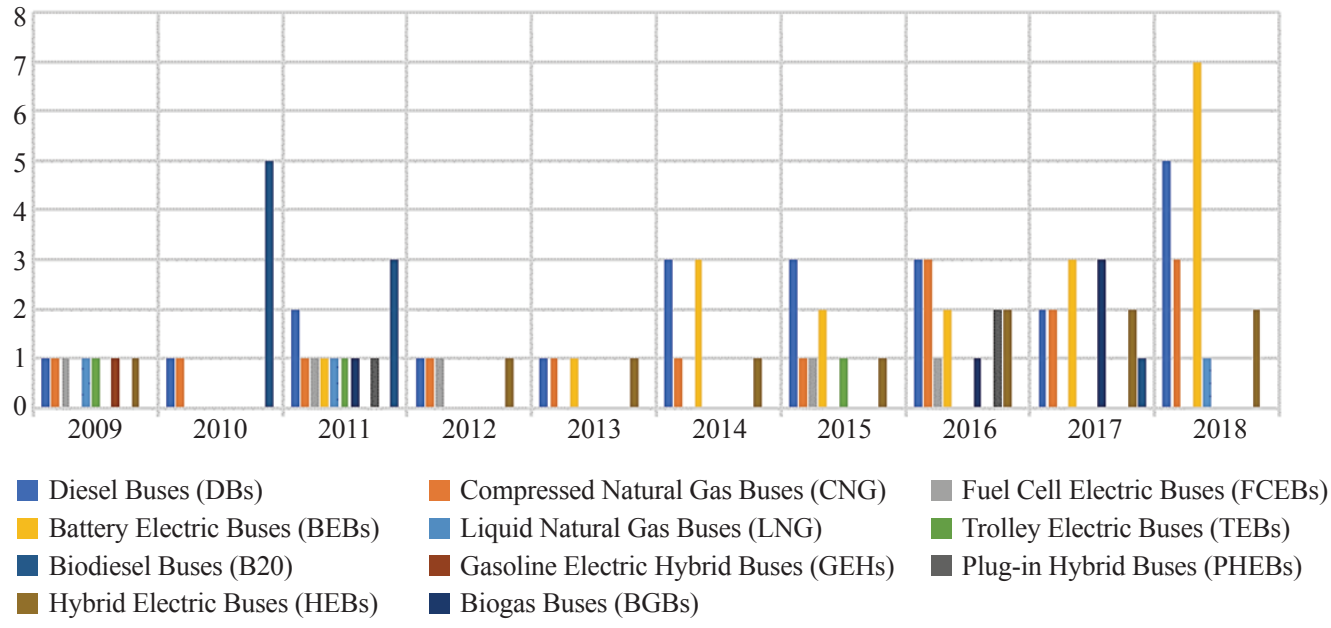

Figure 5-Types of buses used in the research 


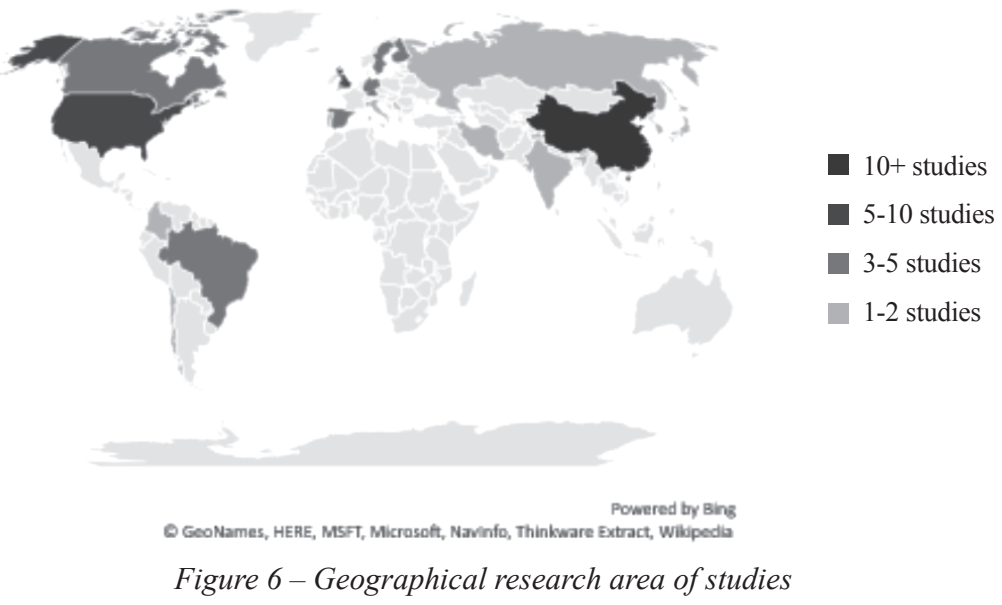

and fuel cell technology [12, 26, 63-65] (Figure 5). Rhetorically, retrofitting and sustainability issues further opened a chapter of infrastructure-related issues due to the unavailability of a network for recharging and refuelling of electric and fuel cell buses. It seems as if that mutual understanding of this various energy-sustainable technology in terms of the environmental and social aspect, proved to be a win-win situation. However, the research shows progress only in the countries with available technology, where they can validate the results in the real-world setting.

The research case studies were mostly done in Asia, America, and Europe, namely: China (11 studies), the USA (9 studies), the United Kingdom (6 studies), Finland (3), Germany (3 studies), Spain (3 studies), Canada (3 studies), Brazil (3 studies), Sweden ( 3 studies), and the rest of the articles validated the research findings through two or fewer practical studies (Figure 6).

\section{ANALYSIS OF DATA AND DISCUSSION}

After careful considerations of state-of-the-art literature, the authors envelop the most important findings from the corpus of evidence. By responding to the first research question we used state-ofthe-art research aims, which served as an apparatus to justify the research outcome. The evidence shows that the advent of innovation compelled the scholars to go beyond mobility management issues towards the asset management issues with more emphasis on revitalising the existing fleet with respect to environmental demands imposed by the government policies. As a consequence of accepting such radical changes, the landscape of BFM research domain started including the cost-benefit analysis due to the lack of financial incentives and investments in the new fleet. Besides, the development of new bus technologies has become a complicated ordeal lately with infrastructural demands. The need for retrofitting the existing fleets, lack of power supply, fuel efficiency issues, and similar, all produced limited solution space with budget constraints. To help ease the issues the authors propose that the BFM domain should be decomposed into two realms, namely: BFMM (Bus Fleet Mobility Management) and BFAM (Bus Fleet Asset Management). Therefore, addressing the specific point within the BFMS, such as routing and scheduling, will fall under the BFMM realm, and the issues of infrastructure and asset management associate with the BFAM realm. The actions of reducing costs, pollution, and fuel consumption, can implicate both realms, although it depends from which aspect these activities are addressed. Usually, in BFMM practice, these constraints are used with integer programming, and some encapsulate this topic as Mixed Bus Fleet Management (MBFM) [66]. Hence, many concepts of the mixed fleet, such as Green Mixed Bus Fleet Management (GMBFM) [43] and Green Bus Fleet Management (GBFM) [53, 67] have emerged over the years. While GBFM is primarily associated with the pollution reduction in relation to mobility issues, the MBFM focuses on fleet optimisation using, for instance, integer programming, to minimise the costs and energy.

\subsection{Bus Fleet Mobility Management (BFMM) realm}

The purpose of BFMM realm is routing and scheduling, while also including factors that can affect productivity and quality of service: deadhead trips $[38,68]$, idle times $[23,38]$, dwell times due to 
road design [69], way of ticketing [70, 71], platform issues $[10,51]$, headway regularity [72], emission [73], and special events [74]. All of the factors affect mobility managers' optimisation and scheduling whether they are Bus Rapid Transit (BRT) [75, 76] roadways, trolley fixed roadways [77], or conventional infrastructures. Even so, critics are often suspicious with trolley and BRT roadways, calling into question its heavy subsidy rate [63]. On the other side, a lot of different cost-saving methods exist within conventional infrastructures, for instance, eco-driving [78]. Eco-driving is a non-aggressive driving technique employed by drivers for efficient fuel consumption and environmental preservation [73]. With the constant development of ITS systems $[35,71,72,79,80]$, whether they are based on GPS [34, 79-82] or GSM [11], eco-driving can benefit from various strategies to minimise fuel consumption, consequently reducing pollution. These strategies can include the use of different payment systems $[82,83]$, way of ticketing $[61,70,71]$, platform regulation $[10,51]$, and headway regularity [72], and similar.

Even though the goals of BFMM today are to optimise the routes concerning minimal energy utilisation and pollution, before 2009 it was understood as a spare ratio issue, i.e. asset issue [29]. The state-ofthe-art literature shows that most of the BFMM research today uses methods of integer-programming and scheduling algorithms for the optimisation of these issues $[84,85]$. For instance, Zhen [86] uses GA (Genetic Algorithm) to compare bus technologies (DBs, B20, HEBs, FCEBs, BEBs) concerning operating costs and emission suggesting the most appropriate technology for different routes (HEBs and BEBs). Alam et al. [87] simulate operation and GHG emission of DBs and CNG buses to show that CNG buses can reduce emissions by an average of $10 \%$. However, they emphasise that switching to CNG buses seems to be less appealing without traffic jams. Santos et al. [88] analysed the advantages and disadvantages of using BEBs showing a significant improvement in terms of fuel consumption and emission reduction, although with considerable operational costs. From an energy standpoint, Lajunen et al. $[25,89,90]$ researched the requirements for HEBs and BEBs, giving a fully documented LCA analysis for different bus technologies (DBs, CNG, BEBs, HEBs, FCEBs) [91]. The implications show the predominance of BEB over other bus technologies but only in the cases of low average speed.
Even though BEBs and FCEBs are favoured over other bus types, they are still in a technological research domain. Regarding management, the biggest problem at the moment is the slow implementation of these types of buses associated with huge infrastructural issues $[92,93]$. Besides, these fleets notorious for high investment and operational costs, which the authors propose, are a BFAM issue.

\subsection{Bus Fleet Asset Management (BFAM) realm}

The authors address the Bus Fleet Asset Management (BFAM) as a realm of BFM concerned with the management of infrastructure, replacement strategies, and fleet maintenance. BFAM is becoming a topic of need due to clock-speed development of battery and fuel cell technology. Hence, crucial for the fleet management is to consider as many factors as possible when considering the renewal or replacement of the fleet, ensuring a reduced carbon footprint. Within BFM, the asset management is defined by some authors as a "systematic process of operating, maintaining, and upgrading physical assets cost-effectively" [32], thus covering a fraction of proposed mobility management practice, although focusing more on the physical asset availability. After the emergence of EU emission norms, upgrading a fleet was mostly done through retrofitting and re-building practice as a temporary solution, since it showed to be less effective. Remanufacturing the engine or transmission had a similar target of extending the life of a bus for at least 4-10 years [94]; however, with a significant portion of expenses, more maintenance-intensive activities later on. In this regard, considering new technologies, one must consider the location of the manufacturer [95], mostly because it is associated with easy-to-access and service maintenance. The reason above is mostly associated with the fleet replacement policy. Fleet replacement, namely, typically follows a uniform distribution where fleet age and mileage (approx. 8.33 years [95]) usually dictate the pace of fleet renewal. The underlying reason is the fact that it is more comfortable to conduct maintenance for vehicles that are of equally dispersed bus age. Moreover, considering the US practice, which states that bus must remain operational for at least twelve years to qualify for federal funds [32], shows just how much the operability depends on the maintaining quality. Therefore, under the pressure of budget constraints, the agencies 
are using alternative rebuilding programs, such as rehabilitation or remanufacturing [44, 94]. Besides maintenance, the factors affecting replacement of the fleet include gas prices, government subsidies, and programs promoting domestic manufacturing with tax reliefs (e.g. "Buy America mandate" [96]). The replacement and renewal strategies are clearly due to sustainability issues, thus apparently creating a gap for the electrification of the fleet. Following the statement, many studies [63-65, 97-99] dedicate to resolve the difficulties regarding the slow implementation of BEBs by transit agencies. However, due to high investment costs, the need for new facilities, personnel training, and low revenue, transit agencies are quite sceptical of acquiring new technology [63]. The risk of getting "stuck" with expensive technology, is somewhat seen through disruptive technologies. For instance, a revolutionary type of charging (e.g. wireless inductive, solar roofs), the lack of charging infrastructure, the impact on the utility grid, staff maintenance training, and technology shift in battery chemistry, lead to scepticism and sense of fear with transit agencies. Academics suggest that conventional buses should be replaced with HEBs and BEBs, highlighting the slow transition with minimal operational costs and emissions, before complete replacement of the fleet.

\subsection{Final section remarks}

The research of BFM in the traditional school of thought implied mostly routing and scheduling, while today it consists of a large number of activities aimed at assuring socio-economic sustainability. This means that to accept new technologies, such as a fleet of ZEBs, the transit agencies must first resolve all the barriers in the way of accepting such a radical change. These barriers present questions associated with pollution, fuel technology, operational efficiency, infrastructure and asset management issues. The obvious thing is that the present transport management research in underdeveloped countries is mostly dealing with the aspect of timely transport service, neglecting the challenges of emerging technologies. In that sense, the technology transfer practice and gentrification activities should be more in the centre of debate within the consortium of projects, to foster a smoother transition from conventional to the state-of-the-art fleet. Besides, the authors suggest that research and practice should address explicitly two different realms; namely,
BFMM - mobility management optimisation concerning energy and pollution, and BFAM - ensuring operability and sustainability of the transit fleet.

\section{CONCLUSION}

Putting all together, the propositions and tenets of BFM brought little to the table in the sense of clearness behind the concepts since most researchers conceive BFM as various interrelated activities. Therefore, in the future, the academia needs to make more unambiguous results and delineate each study aim related to BFM, whether it is under the $\mathrm{BFMM}$ or BFAM realm. If studies are undertaken akin to our propositions, each of the realms is getting closer to the falsifiability of constructs. Besides, overviewing the problems of a slow transition from conventional to ZEBs, the most important issues are related to financial incentives, tax reduction, and the risk of being stuck with expensive technology. In order to support the EU policy of becoming the first free-carbon continent by 2050 [100], more research calls for attention regarding technology transfer and infrastructure issues. To address these issues, the first-ever conference held in the USA, followed up by the conference in Cologne, Germany [101], had as a goal to answer the simple question: Are ZEBs ready for mass-market deployment? Key messages provided insights regarding the current state-of-thepractice, stating that the global bus fleet is around 3 million in total, while BEBs make up $13 \%$ of which $99 \%$ of those are in China. Interestingly, as reported, there are less than 1,000 FCEBs, of which 400 buses are to be deployed in Europe by 2020, meaning that a growing number of projects and dissemination of the results are yet to be expected. Therefore, the state-of-the-art and the state-of-the-practice need to converge and solidify the groundwork to provide solutions in the procurement of ZEBs. As a consequence of the EU policy targets that imply biodiversity, clean energy, "farm to fork" and other strategies, the authors' future research agenda is dedicated towards mechanisms and drivers for a smooth transition between conventional fleet and the fleet of ZEBs by respecting EU initiatives and policy targets.

MARKO OROŠNJAK, M.Sc. ${ }^{1}$

E-mail: orosnjak@uns.ac.rs

MITAR JOCANOVIĆ, Ph.D. ${ }^{1}$

E-mail: mitarj@uns.ac.rs

BRANKA GVOZDENAC-UROŠEVIĆ, Ph.D. ${ }^{1}$

E-mail: brankagvozdenac@uns.ac.rs 
DRAGOLJUB ŠEVIĆ, Ph.D. ${ }^{1}$

E-mail: sevic@uns.ac.rs

LJUBICA DUĐAK, Ph.D. ${ }^{1}$

E-mail: ljuba@uns.ac.rs

VELIBOR KARANOVIĆ, Ph.D. ${ }^{1}$

E-mail: velja 82@uns.ac.rs

${ }^{1}$ Univerzitet u Novom Sadu, Fakultet tehničkih nauka

Trg Dositeja Obradovića 6, 21000 Novi Sad, Srbija

\section{MENADŽMENT VOZNOG PARKA AUTOBUSA - SISTEMATSKI PREGLED LITERATURE}

\section{ABSTRAKT}

Istraživanje na temu menadžmenta voznog parka (MVP) autobusa trpi značajne promene. Nejasno je da li su ove promene prihvaćene kao tehnološke promene ili kao smena paradigme. Pretpostavlja se da je, nenamerno, MVP i dalje prihvaćen kao organizacija ruta i reda vožnje s jedne strane, dok sa druge to predstavlja strategiju održavanja i smenu flote. Prema tome, autori su sproveli sistematski pregled literature kako bi pregledali postojeće koncepte $i$ škole misli na koji to način zainteresovane strane sagledavaju menadžment voznog parka. Studija je otkrila da MVP treba razumeti kao višedimenzioni sistem, a ne kao jedinstvenu dimenziju usluga poput reda vožnje. Pored toga, rad obuhvata evolucije MVP-a koje prikazuju potrebu za višedimnezionim sistemom apstraktovanih kao „Menadžment mobilnosti voznog par$k a$ “ $i$,Menadžment imovinom voznog parka“. Poteškoće agencija javnog prevoza i njihove sposobnosti da pređu sa konvencionalnih na autobuse nulte emisije ilustruju zašto predlažemo takvu agendu, pri čemu je istraživanje verifikovano kroz potrebe i nauke i prakse.

\section{KLJUČNE REC I}

menadžment voznog parka; menadžment mobilnosti voznog parka; menadžment imovinom voznog parka; sistematski pregled literature;

\section{REFERENCES}

[1] European Commission. Transport sector economic analysis. 2011. Available from: https://ec.europa.eu/jrc/en/ research-topic/transport-sector-economic-analysis [cited 2019 Jun 5].

[2] UITP. Urban Public Transport in $21^{\text {st }}$ Century. Advancing Public Transport. 2017. p. 1-8. Available from: https://www.uitp.org/urban-public-transport-21st-century [cited 2018 Oct 22].

[3] Galbieri R, Brito TLF, Mouette D, de Medeiros Costa HK, Moutinho dos Santos E, Fagá MTW. Bus fleet emissions: new strategies for mitigation by adopting natural gas. Mitig Adapt Strateg Glob Chang. 2018 Oct 12;23(7): 1039-62. Available from: http://link.springer. com/10.1007/s11027-017-9771-y

[4] Jiménez F, Román A. Urban bus fleet-to-route assignment for pollutant emissions minimization. Transp Res Part E. 2016;85: 120-31.
[5] Nurhadi L, Borén S, Ny H. Advancing from Efficiency to Sustainability in Swedish Medium-sized Cities: An Approach for Recommending Powertrains and Energy Carriers for Public Bus Transport Systems. Procedia - Soc Behav Sci. 2014 Feb;111: 1218-25. Available from: https://linkinghub.elsevier.com/retrieve/pii/ S1877042814000937

[6] Worldbank. Transit Bus Operational and Maintenance Practices to Maximize Fuel Economy. 2011;(63116).

[7] Bivona E, Montemaggiore GB. Understanding short- and long-term implications of "myopic" fleet maintenance polices: A system dynamics application to a city bus company. Syst Dyn Rev. 2010;26(3): 195-215.

[8] Zhou Y, Kou G, Ergu D. Analysing Operating Data to Measure the Maintenance Performance. Qual Reliab Eng Int. 2014;31(2): 1-13.

[9] Cats O, Jenelius E. Beyond a complete failure: The impact of partial capacity degradation on public transport network vulnerability. Transp B. 2016;6(2): 77-96. Available from: doi:10.1080/21680566.2016.1267596

[10] Zhou C, Su Z, Hui Z. Bus Fleet Management System for BRT Based on Platform Screen Doors. In: Xinping Y, Ping Y, Chaozhong W, Ming Z, editors. Proceedings of the first International Conference on Transportation Information and Safety. Wuhan, China: American Society of Civil Engineers (ASCE); 2011. p. 26-32.

[11] Osman MM, Sultana MR, Sulthana MS. Enhancement of Public Transportation Services Using Wireless Technologies. Int J Eng Trends Technol. 2013;6(7): 344-8. Available from: http://uta.summon.serialssolutions.com/2.0.0/ link/0/eLvHCXMw3V09T8MwFLRKJxgQn-JT8sRSpWriNHEHBkBFraAg0TJHL7FNQE2K2vL_sWOncQoTMDFFsqVYzjudn1 OZ4SI1-44a5zACCEBBZr4jIpEeHHiMlZYucQBj6k6nPwwDp7ue5OBd9dolLelVW3_IfD9PFWRLH_y67pcZWIONYpoacmA0sBOFeetKü2ltvCtUrrXC4c

[12] Vaughan ML, Faghri A, Li M. An Interactive Expert System Based Decision Making Model for the Management of Transit System Alternate Fuel Vehicle Assets. Intell Inf Manag. 2017;09(01): 1-20. Available from: doi:10.4236/ iim.2017.91001

[13] Wang Y, Huang Y, Xu J, Barclay N. Optimal recharging scheduling for urban electric buses: A case study in Davis. Transp Res Part E Logist Transp Rev. 2017;100: 115-32. Available from: doi:10.1016/j.tre.2017.01.001

[14] Chen X, Han X, Yu L, Wei C. Does operation scheduling make a difference: Tapping the potential of optimized design for skipping-stop strategy in reducing bus emissions. Sustainability. 2017;9(10): 1-18.

[15] Hauslen RA. The promise of automatic vehicle identification. IEEE Trans Veh Technol. 1977 Feb;26(1): 30-8. Available from: http://ieeexplore.ieee.org/document/1622353/

[16] Roth SH. History of automatic vehicle monitoring (AVM). IEEE Trans Veh Technol. 1977 Feb;26(1): 2-6. Available from: http://ieeexplore.ieee.org/document/1622348/

[17] Maze TH, Cook AR, Dutta U. Bus Fleet Management Techniques Guide. Oklahoma, US; 1985.

[18] Belmonte M, Fern A, Rey U, Carlos J. Agent Coordination for Bus Fleet Management. In: ACM Symposium on 
Applied Computing. 2005. p. 462-6.

[19] Belmonte MV, Perez-de-la-Cruz JL, Triguero F. Ontologies and agents for a bus fleet management system. $E x$ pert Syst Appl. 2008;34: 1351-65.

[20] Fernandez A, Ossowski S. A Multiagent Approach to the Dynamic Enactment of Semantic Transportation Services. IEEE Trans Intell Transp Syst. 2011 Jun;12(2): 333-42. Available from: http://ieeexplore.ieee.org/document/5710583/

[21] Ossowski S, Hernandez JZ, Belmonte MV, Maseda J, Fernandez A, Serrano-Garcia A. Multi-agent systems for decision support: A case study in the transportation management domain. Appl Artifical Intell. 2004;18: 779-95.

[22] Gao D, Jin Z, Zhang J, Li J, Ouyang M. Comparative study of two different powertrains for a fuel cell hybrid bus. J Power Sources. 2016;319: 9-18. Available from: doi:10.1016/j.jpowsour.2016.04.046

[23] Gallet M, Massier T, Hamacher T. Estimation of the energy demand of electric buses based on real-world data for large-scale public transport networks. Appl Energy. 2018;230(January): 344-56. Available from: doi:10.1016/j.apenergy.2018.08.086

[24] Holmberg K, Andersson P, Nylund NO, Mäkelä K, Erdemir A. Global energy consumption due to friction in trucks and buses. Tribol Int. 2014;78: 94-114. Available doi:10.1016/j.triboint.2014.05.004

[25] Vepsäläinen J, Kivekäs K, Otto K, Lajunen A, Tammi K. Development and validation of energy demand uncertainty model for electric city buses. Transp Res Part D Transp Environ. 2018;63(June): 347-61. Available from: doi:10.1016/j.trd.2018.06.004

[26] Ngo HH, Shah R, Mishra S. Optimal asset management strategies for mixed transit fleet. Transp Res Part A Policy Pract. 2018;117(October 2017): 103-16. Available from: doi:10.1016/j.tra.2018.08.013

[27] Vaughan ML. Decision making model for the management of transit system alternative fuel infrastructures through the utilization of an interactive expert system interface. University of Delaware; 2017.

[28] Stasko TH, Oliver Gao H. Developing green fleet management strategies: Repair/retrofit/replacement decisions under environmental regulation. Transp Res Part $A$ Policy Pract. 2012 Oct;46(8): 1216-26. Available from: doi:10.1016/j.tra.2012.05.012

[29] APTA. Bus Fleet Management in an Era of Increasing Technical Complexity: Analysis of Bus Fleet Spare Ratios; 2009. Available from: https://www.apta.com

[30] Feng W, Figliozzi MA. Vehicle technologies and bus fleet replacement optimization: Problem properties and sensitivity analysis utilizing real-world data. Public Transp. 2014;6(1-2): 137-57.

[31] Boudart JA. Bus Replacement Modeling and the Impacts of Budget Constraints, Fleet Cost Variability, and Market Changes on Fleet Costs and Optimal Bus Replacement Age, A Case Study. Portland State University; 2011.

[32] Mishra S, Mathew TV, Khasnabis S. Single-Stage Integer Programming Model for Long-Term Transit Fleet Resource Allocation. J Transp Eng. 2010 Apr;136(4): 281-90. Available from: doi:10.1061/\%28ASCE $\% 29073$ 3-947X\%282010\%29136\%3A4\%28281\%29

[33] Pozhivilov N, Automobile MS, Kavalchuk I. The technique of optimal leasing duration estimation for the city bus using technical and economical parameters. SEE-Mie2015, Japan First International Conference on Science, Engineering \& Environment (SEE), 19-21 November 2015,Tsu City, Mie, Japan; 2015. p. 1-7.

[34] Hounsell NB, Shrestha BP, Wong A. Data management and applications in a world-leading bus fleet. Transp Res Part C Emerg Technol. 2012 Jun;22: 76-87. Available doi:10.1016/j.trc.2011.12.005

[35] D'Souza C, Hounsell NB, Shrestha BP. Using automatic vehicle location (AVL) data for evaluation of bus priority at traffic signals. IET and ITS Conference on Road Transport Information and Control (RTIC 2012). London, UK: Institution of Engineering and Technology; 2012. p. 2121. Available from: https://digital-library.theiet.org/content/conferences/10.1049/cp.2012.1550

[36] Polyviou P, Hounsell N, Shrestha B. Modelling incidents for dynamic bus fleet management purposes: A UK perspective. Transp Plan Technol. 2012 Feb;35(1): 49-67. Available from: doi:10.1080/03081060.2012.635416

[37] Cats O, Loutos G. Real-Time Bus Arrival Information System: An Empirical Evaluation. J Intell Transp Syst Technol Planning, Oper. 2016;20(2): 138-51.

[38] Southworth F, Meyer MD, Weigel BA. Transit Greenhouse Gas Emissions Management Compendium. Atlanta, GA, USA: Federal Transit Administration; 2011. Available from: http://www.fta.dot.gov/research

[39] Riechi J, Mácian V, Tormos B, Avila C. Optimal fleet replacement: A case study on a Spanish urban transport fleet. J Oper Res Soc. 2017 Aug 21;68(8): 886-94. Available from: doi:10.1057/s41274-017-0236-1

[40] Mishra S, Sharma S, Khasnabis S, Mathew TV. Preserving an aging transit fleet: An optimal resource allocation perspective based on service life and constrained budget. Transp Res Part A Policy Pract. 2013;47: 111-23. Available from: doi:10.1016/j.tra.2012.10.029

[41] Yu Q, Li T, Li H. Improving urban bus emission and fuel consumption modeling by incorporating passenger load factor for real world driving. Applied Energy. 2016;161: 101-11.

[42] Li L, Lo HK, Xiao F, Cen X. Mixed bus fleet management strategy for minimizing overall and emissions external costs. Transp Res Part D Transp Environ. 2018 May;60: 104-18. Available from: https://linkinghub.elsevier.com/retrieve/pii/S1361920916306757

[43] Li L, Lo HK, Xiao F, Cen X. Green mixed bus fleet management strategy. In: Transport and Society - Proceeding of the $22^{\text {nd }}$ International Conference of Hong Kong Society for Transportation Studies, HKSTS 2017; 2017.

[44] Li L, Lo HK, Cen X. Optimal bus fleet management strategy for emissions reduction. Transp Res Part D Transp Environ. 2015;41: 330-47.

[45] De A, Do N. Integrating Electric Buses in Conventional Public Transit: A First Appraisal. Universidade do Porto; 2016.

[46] Emiliano W, Costa L, Carvalho M do S, Telhada J. Bus Fleet Management Optimization Using the Augmented Weighted Tchebycheff Method. In: Vaz AIF, Almeida JP, Olivieira JF, Pinto AA, editors. Operational Research. Valença, Portugal: Springer; 2018. p. 201-13.

[47] Emiliano W, Costa L, Carvalho SM, Telhada J, Lanzer 
EA. Multiobjective optimization of transit bus fleets with alternative fuel options: The case of Joinville, Brazil. Int J Sustain Transp. 2019;0(0): 1-11. Available from: doi: 10.1080/15568318.2018.1518500

[48] Zhen F. Optimization Tool for Transit Bus Fleet Management. West Virginia University; 2012.

[49] Filippone F, Pugliese M, Manager L, Italia B, Roma SA. TLC facilities applied to the management of an integrated system of public and private mobility in a large city. $5^{\text {th }}$ International Congress on Energy, Environment and Technological Innovation EETI 2004. Rio de Janeiro, Brazil; 2004. p. 1-6.

[50] KonSULT. Bus Fleet Management Systems. Policy Instruments: A policy Guidebook. 2016. Available from: http:// www.konsult.leeds.ac.uk/pg/34/ [cited 2019 Feb 3].

[51] Zhou C. Platform Screen Doors Enhanced Bus Rapid Transit Intelligent Performance. Int J Inf Eng Electron Bus. 2011;3: 52-9.

[52] Perhinschi MG, Marlowe C, Tamayo S, Tu J, Wayne WS. Evolutionary Algorithm for Vehicle Driving Cycle Generation. J Air Waste Manage Assoc. 2011 Sep 29;61(9): 923-31. Available from: doi:10.1080/10473289.2011.59 6742

[53] Vaughan ML, Faghri A, Li M. Knowledge-based decision-making model for the management of transit system alternative fuel infrastructures. Int J Sustain Dev World Ecol. 2018 Feb 17;25(2): 184-94. Available from: doi:10. 1080/13504509.2017.1333541

[54] Krawiec S, Karoń G, Janecki R, Sierpiński G, Krawiec K, Markusik S. Economic Conditions to Introduce the Battery Drive to Busses in the Urban Public Transport. Transp Res Procedia. 2016;14: 2630-9. Available from: https://linkinghub.elsevier.com/retrieve/pii/ S2352146516304264

[55] Yoshioka LR, Santos GHR, Costa RD, Vas A. Case Studies of the Fleet Operational Efficiency Gains through Onboard Intelligence and Managerial Processes. SAE Technical Paper 2010-36-0332, 2010. p. 1-12. Available from: https://www.sae.org/content/2010-36-0332/

[56] Gong J, Wu C. A transit fleet replacement model for emissions reduction. Proceedings of 2011 IEEE International Conference on Service Operations, Logistics and Informatics; 2011. p. 22-5.

[57] Achimugu P, Selamat A, Ibrahim R, Naz M. A systematic literature review of software requirements prioritization research. Inf Softw Technol. 2014;56(6): 568-85. Available doi:10.1016/j.infsof.2014.02.001

[58] Tranfield D, Denyer D, Smart P. Towards a Methodology for Developing Evidence-Informed Management Knowledge by Means of Systematic Review. Br J Manag. 2003 Sep;14(3): 207-22. Available from: doi:10.1111/14678551.00375

[59] Cronin P, Ryan F, Coughlan M. Undertaking a Literature Review: A step-by-step approach. Br J Nurs. 2004;17(1): 38-43.

[60] Moher D, Liberati A, Tetzlaff J, Altman DG. Preferred Reporting Items for Systematic Reviews and Meta-Analyses: The PRISMA Statement. PLoS Med. 2009 Jul 21;6(7): e1000097. Available from: doi:10.1371/journal. pmed.1000097

[61] Ferreira ML, de Gouveia JAM, Fachchini E, Pokorny
MS, Dias EM. Real time monitoring of public transit passenger flows through Radio Frequency Identification - RFID technology embedded in fare smart cards. Latest Trends Syst. 2012;II: 599-605.

[62] Cai X. Collaborative prediction for bus arrival time based on CPS. J Cent South Univ. 2014 Mar 16;21(3): 12428. Available from: http://link.springer.com/10.1007/ s11771-014-2058-5

[63] Mohamed M, Ferguson M, Kanaroglou P. What hinders adoption of the electric bus in Canadian transit? Perspectives of transit providers. Transp Res Part D. 2018;64(August 2017): 134-49. Available from: doi:10.1016/j.trd.2017.09.019

[64] Rogge M, Wollny S, Sauer D. Fast Charging Battery Buses for the Electrification of Urban Public Transport-A Feasibility Study Focusing on Charging Infrastructure and Energy Storage Requirements. Energies. 2015 May 21;8(5): 4587-606. Available from: http://www.mdpi. com/1996-1073/8/5/4587

[65] Rogge M, van der Hurk E, Larsen A, Sauer DU. Electric bus fleet size and mix problem with optimization of charging infrastructure. Appl Energy. 2018;211(February 2017): 282-95. Available from: doi:10.1016/j.apenergy.2017.11.051

[66] Li L, Lo HK, Xiao F, Cen X. Mixed bus fleet management strategy for minimizing overall and emissions external costs. Transp Res Part D Transp Environ. 2018;60: 104-18.

[67] Stasko TH, Oliver Gao H. Reducing transit fleet emissions through vehicle retrofits, replacements, and usage changes over multiple time periods. Transp Res Part D Transp Environ. $2010 \mathrm{Jul} ; 15(5)$ : 254-62. Available from: doi:10.1016/j.trd.2010.03.004

[68] Nasibov E, Eliiyi U, Erac MO, Kuvvetli U. Deadhead trip minimization in city bus transportation: A real life application. Promet - Traffic\& Transportation. 2013;25(2): $137-45$.

[69] Cats O, Loutos G. Evaluating the added-value of online bus arrival prediction schemes. Transp Res Part A Policy Pract. 2016;86: 35-55. Available from: doi:10.1016/ j.tra.2016.02.004

[70] Fletcher G, El-Geneidy A. Effects of Fare Payment Types and Crowding on Dwell Time. Transp Res Rec J Transp Res Board. 2013 Jan;2351(1): 124-32. Available from: doi:10.3141/2351-14

[71] Guirao B, García A, López M, Acha C, Comendador J. New QR Survey Methodologies to Analyze User Perception of Service Quality in Public Transport: The Experience of Madrid. J Public Transp. 2015 Sep;18(3): 7188. Available from: http://scholarcommons.usf.edu/jpt/ vol18/iss $3 / 5 /$

[72] Hosseini-Motlagh S-M, Ahadpour P, Haeri A. Proposing an approach to calculate headway intervals to improve bus fleet scheduling using a data mining algorithm. 2015;8(4): 72-86.

[73] Zhang L, Liang W, Zheng X. Eco-Driving for Public Transit in Cyber-Physical Systems Using V2I Communication. Int J Intell Transp Syst Res. 2018;16(2): 79-89.

[74] Polyviou P. A new micro-simulation approach to model the impacts of bus and traffic incidents on bus performance The bus operators' perspective. European Transport 
Conference, 10-12 October 2011, Glasgow, UK. Association for European Transport and Contributors; 2011. p. $1-14$.

[75] Kumara BH. Planning for Bus Rapid Transit System (BRTS) in Indian Metropolitan Cities: Challenges and options. Inst T Planners, India J. 2009;6(4): 9-21.

[76] Ardila DS, Parker B, Perry D. Policy mobilities and urban change: The case of bus rapid transit in Colombia. University of Illinois Chicago; 2016.

[77] Misanovic S, Zivanovic Z, Tica S. Energy efficiency of different bus subsystems in Belgrade public transport. Therm Sci. 2015;19(6): 2233-44. Available from: http://www.doiserbia.nb.rs/Article.aspx?ID $=0354-98361500193 \mathrm{M}$

[78] Li D, Li L, Meng H, Zhang W. Integrated Dynamic Transit Operation System for Multimodal Suburban Transit. $201821^{\text {st }}$ International Conference on Intelligent Transportation Systems (ITSC), 4-7 Nov. 2018, Maui, HI, USA. IEEE; 2018. p. 3662-7. Available from: https://ieeexplore.ieee.org/document/8569231

[79] D'Souza C, Gardner K, Hounsell NB, Shrestha BP. New developments for bus priority at traffic signals in London using iBus. IET Road Transport Information and Control Conference and the ITS United Kingdom Members Conference (RTIC 2010) Better transport through technology. IET; 2010. p. 72-72. Available from: doi:0.1049/ cp.2010.0386\#

[80] Predic B, Rancic D, Milosavljevic A. Impacts of applying automated vehicle location systems to public bus transport management. J Res Pract Inf Technol. 2010;42(2): 79-98.

[81] Wong A, Hounsell N. Using the iBus system to provide improved public transport information and applications for London. $12^{\text {th }}$ WCTR. Lisbon, Portugal; 2010. p. 1-10.

[82] Beltrán P, Gschwender A, Palma C. The impact of compliance measures on the operation of a bus system: The case of Transantiago. Res Transp Econ. 2013 Mar;39(1): 79-89. Available from: doi:10.1016/j.retrec.2012.05.026

[83] Tang C, Ceder A, Ge Y. Optimal public-transport operational strategies to reduce cost and vehicle's emission. PLoS One. 2018;13(8): 1-17.

[84] Zhang Q. Simulation of Agent-Based of Intelligent Public Transit System. Proceedings of 2011 International Conference on Electronic Engineering, Communication and Management, Beijing, China. Springer; 2012. p. 129-35. Available from: doi:10.1007/978-3-642-27296721

[85] Chao Z, Xiaohong C. Optimizing Battery Electric Bus Transit Vehicle Scheduling with Battery Exchanging: Model and Case Study. Procedia - Soc Behav Sci. 2013 Nov;96(Cictp): 2725-36. Available from: http://linkinghub.elsevier.com/retrieve/pii/S1877042813024324

[86] Zhen F. Optimization tool for transit bus fleet management. West Virginia University; 2012.

[87] Alam A, Hatzopoulou M. Reducing transit bus emissions: Alternative fuels or traffic operations? Atmos Environ. 2014 Jun;89: 129-39. Available from: doi:10.1016/ j.atmosenv.2014.02.043

[88] Santos D, Kokkinogenis Z, Sousa JF De, Perrotta D, Rossetti RJF, Ieee M. Towards the Integration of Electric Buses in Conventional Bus Fleets. $19^{\text {th }}$ International
Conference on Intelligent Transportation Systems (ITSC), Rio de Janeiro, Brazil. IEEE; 2016. p. 88-93.

[89] Lajunen A. Energy consumption and cost-benefit analysis of hybrid and electric city buses. Transp Res Part C Emerg Technol. 2014;38: 1-15. Available from: doi:10.1016/j.trc.2013.10.008

[90] Lajunen A. Lifecycle costs and charging requirements of electric buses with different charging methods. $J$ Clean Prod. 2018 Jan;172: 56-67. Available from: doi:10.1016/j.jclepro.2017.10.066

[91] Lajunen A, Lipman T. Lifecycle cost assessment and carbon dioxide emissions of diesel, natural gas, hybrid electric, fuel cell hybrid and electric transit buses. Energy. 2016 Jul;106: 329-42. Available from: doi:10.1016/j. energy.2016.03.075

[92] Xylia M, Leduc S, Patrizio P, Kraxner F, Silveira S. Locating charging infrastructure for electric buses in Stockholm. Transp Res Part C Emerg Technol. 2017 May;78: 183-200. Available from: doi:10.1016/j.trc.2017.03.005

[93] Paul T, Yamada H. Operation and charging scheduling of electric buses in a city bus route network. $17^{\text {th }}$ IEEE International Conference on Intelligent Transportation Systems (ITSC), 8-11 Oct. 2014, Qingdao, China; 2014. p. 2780-6.

[94] Mathew TV, Khasnabis S, Mishra S. Optimal resource allocation among transit agencies for fleet management. Transp Res Part A Policy Pract. 2010 Jul;44(6): 418-32. Available from: doi:10.1016/j.tra.2010.03.016

[95] Li S, Kahn ME, Nickelsburg J. The Political Economy of Public Bus Procurement: The Role of Regulation, Energy Prices and Federal Subsidies; 2013.

[96] Li S, Kahn ME, Nickelsburg J. Public transit bus procurement: The role of energy prices, regulation and federal subsidies. J Urban Econ. 2015 May;87: 57-71. Available from: doi:10.1016/j.jue.2015.01.004

[97] Mohamed M, Farag H, El-Taweel N, Ferguson M. Simulation of electric buses on a full transit network: Operational feasibility and grid impact analysis. Electr Power Syst Res. 2017;142: 163-75. Available from: doi:10.1016/j.epsr.2016.09.032

[98] Bi Z, De Kleine R, Keoleian GA. Integrated Life Cycle Assessment and Life Cycle Cost Model for Comparing Plug-in versus Wireless Charging for an Electric Bus System. J Ind Ecol. 2017 Apr;21(2): 344-55. Available from: doi:10.1111/jiec.12419

[99] Gabsalikhova L, Sadygova G, Almetova Z. Activities to convert the public transport fleet to electric buses. Transp Res Procedia. 2018;36: 669-75. Available from: doi:10.1016/j.trpro.2018.12.127

[100] European Commission. Orientations Towards the First Strategic Plan for Horizon Europe; 2019. p. 1-164. Available from: https://ec.europa.eu/info/sites/info/ files/research_and_innovation/strategy_on_research_ and innovation/documents/ec rtd he-orientations-towards-strategic-plan_102019.pdf [cited 2019 Dec 3].

[101] ZEB. 2018 European Zero Emission Bus Conference Report. JIVE 2; 2018. p. 2018-20. Available from: http:// zebconference.com/wp-content/uploads/2019/02/Appendix-3-Conference-Report.pdf [cited 2019 Mar 25]. 